\title{
Garnets from the Camafuca-Camazambo kimberlite (Angola)
}

\author{
EUGÉNIO A. CORREIA and FERNANDO A.T.P. LAIGINHAS \\ Departamento de Geologia, Faculdade de Ciências da Universidade do Porto \\ Praça de Gomes Teixeira, 4050 Porto, Portugal \\ Manuscript received on November 17, 2004; accepted for publication on June 13, 2005; \\ presented by ALCIDES N. SIAL
}

\begin{abstract}
This work presents a geochemical study of a set of garnets, selected by their colors, from the CamafucaCamazambo kimberlite, located on northeast Angola. Mantle-derived garnets were classified according to the scheme proposed by Grütter et al. (2004) and belong to the G1, G4, G9 and G10 groups.

Both sub-calcic (G10) and Ca-saturated (G9) garnets, typical, respectively, of harzburgites and lherzolites, were identified. The solubility limit of knorringite molecule in G10D garnets suggests they have crystallized at a minimum pressure of about 40 to $45 \mathrm{kbar}(4-4.5 \mathrm{GPa})$. The occurrence of diamond stability field garnets (G10D) is a clear indicator of the potential of this kimberlite for diamond. The chemistry of the garnets suggests that the source for the kimberlite was a lherzolite that has suffered a partial melting that formed basaltic magma, leaving a harzburgite as a residue.
\end{abstract}

Key words: kimberlite, diamond, garnet, lherzolite, harzburgite.

\section{INTRODUCTION}

The Camafuca-Camazambo kimberlite belongs to a kimberlite province comprising over a dozen of primary occurrences of diamond, located alongside the homonymous brook which is a tributary of the Chicapa river, in the proximity of the Calonda village, northeast Angola (Fig. 1). The CamafucaCamazambo kimberlite spans over an area of about 36 hectares, intruding into clayey-sandstones and tills of the Karroo Group, and gneisses of the Base Complex. Its shape suggests conditioning by a system of local fractures with NNW and ENE directions (Real 1958). Among this kimberlite province, the Camafuca-Camazambo intrusion is the largest body and the one presenting the greatest economic potential.

Correspondence to: Eugénio A. Correia

E-mail: eacorrei@fc.up.pt

\section{GEOCHEMICAL STUDY OF GARNETS}

The geochemical study of mantle-derived garnets occurring in kimberlites progressed remarkably in recent years, as their chemistry is not only a possible indicator of the presence of diamonds in their host rock but also their abundance is a likely indicator of the economic potential of the kimberlite.

Sub-calcic chrome-pyropes, commonly designated G10, are the type of mantle-derived garnets that may give these indications. The occurrence of these characteristically purple-colored garnets is rare, being usually confined to diamondiferous kimberlites. Their occurrence as inclusions in diamonds of the peridotitic paragenesis suggests they are mineral phases that are stable in the nucleation and growth environment of diamond.

The study presented in this paper has been made on garnets that were visually separated from 


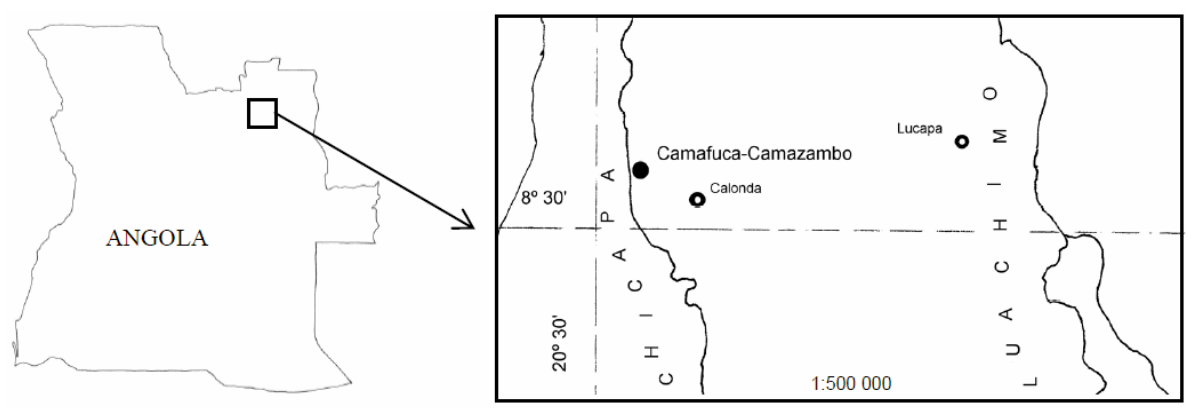

Fig. 1 - Location of the Camafuca-Camazambo kimberlite, northeast Angola.

others from concentrates of the kimberlite mentioned above. The grains show distinct morphology, from well-rounded to angular. In macroscopic observation, the garnet grains are more or less transparent, with red or purple red color.

\section{ANALYTICAL METHODS}

Element concentrations were determined on a $\mathrm{Ca}$ meca CAMEBAX electron microprobe equipped with a WDS detector, using ZAF correction routines, at the INETI Laboratory in S. Mamede de Infesta, Portugal. Analytical conditions involved an acceleration voltage of $15 \mathrm{kV}$ and a beam current of $20 \mathrm{nA}$, with counting times of 10 seconds in peak and 5 seconds in background.

Several natural and synthetic materials were used as standards: orthoclase as a standard for $\mathrm{Si}$ and $\mathrm{Al}, \mathrm{MgO}$ for $\mathrm{Mg}, \mathrm{MnTiO}_{3}$ for $\mathrm{Ti}$ and $\mathrm{Mn}$, albite for $\mathrm{Na}$, andaluzite for $\mathrm{Ca}, \mathrm{Fe}_{2} \mathrm{O}_{3}$ for $\mathrm{Fe}, \mathrm{Cr}_{2} \mathrm{O}_{3}$ for $\mathrm{Cr}$ and metallic nickel for $\mathrm{Ni}$.

\section{RESULTS}

A total of 22 red to purple red colored garnet grains were submitted to multi-elementary punctual chemical analysis (Fig. 2; Table I) and were classified according to the classification scheme for mantlederived garnets proposed by Grütter et al. (2004), a refinement of the standard and well known G10/G9 classification developed by Gurney (1984). Among them, 9 belong to the G10 group of garnets from harzburgites, 3 to the G9 group of garnets from lher- zolites, 10 to the G1 group of megacrystic garnets, and 1 to the $\mathrm{G} 4$ group, which comprises garnets from pyroxenites, eclogites and websterites.

In the analyzed $\mathrm{G} 10$ garnets, $\mathrm{Cr}_{2} \mathrm{O}_{3}$ contents are relatively low (ca. 4 to $5 \mathrm{wt} . \%$ ) and $\mathrm{CaO}$ contents are too high (ca. 3 to $4 \mathrm{wt} . \%$ ) to permit their differentiation as diamond-facies G10 garnets. However, as all garnet grains have $\mathrm{MnO}$ contents lower than 0.36 wt. $\%$, the "D" suffix, attributed to garnets that show compositional and pressure-temperature conditions similar to those for the diamond stability, can be added (see Grütter et al. 2004).

The grain Gnt17 stands out from the others for its low (0.97 wt.\%) $\mathrm{Cr}_{2} \mathrm{O}_{3}$ contents. It is most probably a pyroxenitic $\mathrm{G} 4$ sub-calcic garnet (Grütter et al. 2004) particularly enriched in the almandine component (ca. $25 \mathrm{~mol} \%$ ).

Garnets of the G9 group also have relatively low $\mathrm{Cr}_{2} \mathrm{O}_{3}$ amounts (between 2 and 3 wt. \%) and can only be separated from G1 group garnets because they are much poorer in $\mathrm{TiO}_{2}(0.25 \mathrm{wt} . \%)$ than the latter (0.30 to $0.94 \mathrm{wt} . \%)$.

Even after careful visual examination, a large number of garnet megacrysts of the G1 group from this kimberlite were undistinguishable from the other mantle-derived garnets that were chemically analyzed. Nevertheless, this fact was expected because megacrystic garnets are relatively Fe-rich and Ti-rich and generally endure chemical weathering better than several other mantle-derived garnets. Even though there is no established relationship between megacrystic garnets and diamond, their 
TABLE I

Chemical analysis of garnets from the Camafuca-Camazambo kimberlite, northeast Angola.

\begin{tabular}{|c|c|c|c|c|c|c|c|c|c|c|c|}
\hline Designation & Gnt1 & Gnt2 & Gnt3 & Gnt4 & Gnt5 & Gnt6 & Gnt7 & Gnt8 & Gnt9 & Gnt10 & Gnt11 \\
\hline Classification & G1 & G1 & G1 & G1 & G1 & G9 & G1 & G1 & G1 & G1 & G9 \\
\hline $\mathrm{SiO}_{2}$ & 43.34 & 43.84 & 42.76 & 43.34 & 43.84 & 43.40 & 43.37 & 42.87 & 42.93 & 42.71 & 42.67 \\
\hline $\mathrm{TiO}_{2}$ & 0.83 & 0.94 & 0.94 & 0.46 & 0.41 & 0.35 & 0.39 & 0.84 & 0.42 & 0.78 & 0.25 \\
\hline $\mathrm{Al}_{2} \mathrm{O}_{3}$ & 20.33 & 20.27 & 20.07 & 21.05 & 21.32 & 20.90 & 20.76 & 18.60 & 20.62 & 18.72 & 20.57 \\
\hline $\mathrm{Cr}_{2} \mathrm{O}_{3}$ & 1.15 & 1.17 & 1.10 & 1.81 & 1.76 & 1.93 & 2.21 & 3.39 & 2.26 & 3.51 & 2.79 \\
\hline $\mathrm{FeO}$ & 8.98 & 9.05 & 8.52 & 7.75 & 7.70 & 7.26 & 6.96 & 7.66 & 7.57 & 8.22 & 6.48 \\
\hline $\mathrm{MnO}$ & 0.16 & 0.17 & 0.21 & 0.08 & 0.20 & 0.15 & 0.22 & 0.14 & 0.14 & 0.00 & 0.21 \\
\hline $\mathrm{MgO}$ & 21.42 & 21.36 & 20.82 & 21.12 & 21.13 & 20.70 & 20.84 & 20.44 & 21.36 & 21.01 & 21.84 \\
\hline $\mathrm{CaO}$ & 4.08 & 3.89 & 4.17 & 4.54 & 4.31 & 4.19 & 4.14 & 4.60 & 4.15 & 4.71 & 4.24 \\
\hline $\mathrm{Na}_{2} \mathrm{O}$ & 0.10 & 0.06 & 0.07 & 0.03 & 0.03 & 0.05 & 0.05 & 0.09 & 0.05 & 0.09 & 0.03 \\
\hline $\mathrm{NiO}$ & 0.00 & 0.00 & 0.07 & 0.00 & 0.00 & 0.05 & 0.00 & 0.13 & 0.00 & 0.00 & 0.03 \\
\hline Totals & 100.40 & 100.73 & 98.72 & 100.18 & 100.70 & 98.98 & 98.94 & 98.75 & 99.50 & 99.75 & 99.12 \\
\hline
\end{tabular}

Total iron as $\mathrm{FeO}$

\begin{tabular}{|c|c|c|c|c|c|c|c|c|c|c|c|}
\hline \multicolumn{12}{|c|}{ Number of cations on the basis of 12 oxygens } \\
\hline $\mathrm{Si}$ & 3.07 & 3.09 & 3.08 & 3.07 & 3.08 & 3.10 & 3.09 & 3.10 & 3.06 & 3.07 & 3.05 \\
\hline $\mathrm{Ti}$ & 0.04 & 0.05 & 0.05 & 0.02 & 0.02 & 0.02 & 0.02 & 0.05 & 0.02 & 0.04 & 0.01 \\
\hline $\mathrm{Al}$ & 1.70 & 1.69 & 1.70 & 1.75 & 1.77 & 1.76 & 1.75 & 1.58 & 1.73 & 1.58 & 1.73 \\
\hline $\mathrm{Cr}$ & 0.06 & 0.07 & 0.06 & 0.10 & 0.10 & 0.11 & 0.12 & 0.19 & 0.13 & 0.20 & 0.16 \\
\hline $\mathrm{Fe}^{2+}$ & 0.53 & 0.53 & 0.51 & 0.46 & 0.45 & 0.43 & 0.42 & 0.46 & 0.45 & 0.49 & 0.39 \\
\hline $\mathrm{Mn}$ & 0.01 & 0.01 & 0.01 & 0.00 & 0.01 & 0.01 & 0.01 & 0.01 & 0.01 & 0.00 & 0.01 \\
\hline $\mathrm{Mg}$ & 2.26 & 2.25 & 2.23 & 2.23 & 2.21 & 2.20 & 2.22 & 2.20 & 2.27 & 2.25 & 2.32 \\
\hline $\mathrm{Ca}$ & 0.31 & 0.29 & 0.32 & 0.34 & 0.32 & 0.32 & 0.32 & 0.36 & 0.32 & 0.36 & 0.32 \\
\hline $\mathrm{Na}$ & 0.01 & 0.01 & 0.01 & 0.00 & 0.00 & 0.01 & 0.01 & 0.01 & 0.01 & 0.01 & 0.00 \\
\hline $\mathrm{Ni}$ & 0.00 & 0.00 & 0.00 & 0.00 & 0.00 & 0.00 & 0.00 & 0.01 & 0.00 & 0.00 & 0.00 \\
\hline Totals & 8.01 & 7.99 & 7.99 & 7.98 & 7.97 & 7.96 & 7.95 & 7.97 & 7.99 & 8.01 & 8.00 \\
\hline & & & & & & & & & & & \\
\hline $\mathrm{Mg} \#$ & 80.97 & 80.80 & 81.32 & 82.93 & 83.03 & 83.55 & 84.23 & 82.62 & 83.42 & 81.99 & 85.72 \\
\hline $\mathrm{Ca} \#$ & 12.04 & 11.57 & 12.59 & 13.38 & 12.78 & 12.70 & 12.50 & 13.92 & 12.24 & 13.88 & 12.25 \\
\hline $\mathrm{Cr} \#$ & 3.66 & 3.72 & 3.53 & 5.46 & 5.24 & 5.83 & 6.67 & 10.90 & 6.84 & 11.18 & 8.33 \\
\hline
\end{tabular}

\begin{tabular}{|c|c|c|c|c|c|c|c|c|c|c|c|}
\hline \multicolumn{12}{|c|}{ Endmembers (mol.\%) } \\
\hline Pyrope $(\mathrm{Mg})$ & 72.89 & 73.07 & 72.79 & 73.51 & 74.03 & 74.49 & 75.18 & 72.89 & 74.72 & 72.42 & 76.56 \\
\hline Almandine $(\mathrm{Fe})$ & 17.14 & 17.37 & 16.72 & 15.14 & 15.13 & 14.67 & 14.08 & 15.33 & 14.85 & 15.90 & 12.75 \\
\hline Grossular $(\mathrm{Ca})$ & 9.98 & 9.56 & 10.49 & 11.35 & 10.84 & 10.84 & 10.74 & 11.78 & 10.43 & 11.68 & 10.69 \\
\hline
\end{tabular}


TABLE I (continuation)

\begin{tabular}{l|c|c|c|c|c|c|c|c|c|c|c}
\hline Designation & Gnt12 & Gnt13 & Gnt14 & Gnt15 & Gnt16 & Gnt17 & Gnt18 & Gnt19 & Gnt20 & Gnt21 & Gnt22 \\
\hline Classification & G10D & G10D & G9 & G10D & G10D & G4 & G10D & G10D & G10D & G1 & G10D \\
\hline $\mathrm{SiO}_{2}$ & 43.17 & 43.42 & 42.85 & 43.21 & 42.86 & 42.71 & 43.29 & 43.11 & 43.82 & 43.10 & 43.73 \\
\hline $\mathrm{TiO}_{2}$ & 0.01 & 0.01 & 0.05 & 0.07 & 0.05 & 0.09 & 0.00 & 0.01 & 0.04 & 0.52 & 0.00 \\
\hline $\mathrm{Al}_{2} \mathrm{O}_{3}$ & 19.89 & 19.81 & 21.04 & 20.09 & 19.67 & 21.74 & 20.18 & 19.44 & 20.27 & 19.73 & 19.45 \\
\hline $\mathrm{Cr}_{2} \mathrm{O}_{3}$ & 4.83 & 4.85 & 2.50 & 4.45 & 4.57 & 0.97 & 3.99 & 4.55 & 4.49 & 2.95 & 4.35 \\
\hline $\mathrm{FeO}$ & 7.50 & 7.43 & 7.85 & 7.53 & 7.64 & 12.13 & 7.29 & 7.47 & 7.33 & 7.23 & 7.66 \\
\hline $\mathrm{MnO}$ & 0.17 & 0.03 & 0.28 & 0.08 & 0.19 & 0.25 & 0.28 & 0.14 & 0.33 & 0.13 & 0.02 \\
\hline $\mathrm{MgO}$ & 21.46 & 21.47 & 20.08 & 22.34 & 21.31 & 19.19 & 21.84 & 21.20 & 22.15 & 21.12 & 21.54 \\
\hline $\mathrm{CaO}$ & 3.88 & 3.54 & 4.40 & 3.25 & 3.80 & 2.05 & 2.78 & 3.23 & 2.64 & 4.28 & 3.93 \\
\hline $\mathrm{Na} 2 \mathrm{O}$ & 0.00 & 0.00 & 0.05 & 0.07 & 0.01 & 0.05 & 0.01 & 0.01 & 0.07 & 0.06 & 0.00 \\
\hline $\mathrm{NiO}$ & 0.05 & 0.00 & 0.02 & 0.00 & 0.07 & 0.02 & 0.00 & 0.00 & 0.07 & 0.04 & 0.00 \\
\hline Totals & 100.94 & 100.55 & 99.13 & 101.07 & 100.17 & 99.20 & 99.66 & 99.16 & 101.20 & 99.17 & 100.68 \\
\hline Total iron as $\mathrm{FeO}$ & \multicolumn{9}{|l}{}
\end{tabular}

\begin{tabular}{|c|c|c|c|c|c|c|c|c|c|c|c|}
\hline \multicolumn{12}{|c|}{ Number of cations on the basis of 12 oxygens } \\
\hline $\mathrm{Si}$ & 3.05 & 3.07 & 3.07 & 3.04 & 3.05 & 3.08 & 3.08 & 3.09 & 3.07 & 3.08 & 3.09 \\
\hline $\mathrm{Ti}$ & 0.00 & 0.00 & 0.00 & 0.00 & 0.00 & 0.00 & 0.00 & 0.00 & 0.00 & 0.03 & 0.00 \\
\hline $\mathrm{Al}$ & 1.66 & 1.65 & 1.78 & 1.67 & 1.65 & 1.85 & 1.69 & 1.64 & 1.67 & 1.66 & 1.62 \\
\hline $\mathrm{Cr}$ & 0.27 & 0.27 & 0.14 & 0.25 & 0.26 & 0.06 & 0.22 & 0.26 & 0.25 & 0.17 & 0.24 \\
\hline $\mathrm{Fe}^{2+}$ & 0.44 & 0.44 & 0.47 & 0.44 & 0.46 & 0.73 & 0.43 & 0.45 & 0.43 & 0.43 & 0.45 \\
\hline $\mathrm{Mn}$ & 0.01 & 0.00 & 0.02 & 0.00 & 0.01 & 0.02 & 0.02 & 0.01 & 0.02 & 0.01 & 0.00 \\
\hline $\mathrm{Mg}$ & 2.26 & 2.26 & 2.15 & 2.34 & 2.26 & 2.06 & 2.31 & 2.26 & 2.31 & 2.25 & 2.27 \\
\hline $\mathrm{Ca}$ & 0.29 & 0.27 & 0.34 & 0.24 & 0.29 & 0.16 & 0.21 & 0.25 & 0.20 & 0.33 & 0.30 \\
\hline $\mathrm{Na}$ & 0.00 & 0.00 & 0.01 & 0.01 & 0.00 & 0.01 & 0.00 & 0.00 & 0.01 & 0.01 & 0.00 \\
\hline $\mathrm{Ni}$ & 0.00 & 0.00 & 0.00 & 0.00 & 0.00 & 0.00 & 0.00 & 0.00 & 0.00 & 0.00 & 0.00 \\
\hline Totals & 7.99 & 7.97 & 7.97 & 8.00 & 7.99 & 7.97 & 7.97 & 7.96 & 7.97 & 7.98 & 7.98 \\
\hline & & & & & & & & & & & \\
\hline $\mathrm{Mg} \#$ & 83.61 & 83.75 & 82.02 & 84.10 & 83.26 & 73.83 & 84.22 & 83.49 & 84.34 & 83.88 & 83.37 \\
\hline $\mathrm{Ca} \#$ & 11.49 & 10.61 & 13.62 & 9.46 & 11.36 & 7.14 & 8.39 & 9.87 & 7.90 & 12.71 & 11.59 \\
\hline $\mathrm{Cr} \#$ & 14.00 & 14.10 & 7.38 & 12.92 & 13.49 & 2.90 & 11.72 & 13.57 & 12.95 & 9.12 & 13.06 \\
\hline \multicolumn{12}{|c|}{$\mathrm{Mg} \#=100 \mathrm{Mg} /\left(\mathrm{Mg}+\mathrm{Fe} 2^{+}\right), \mathrm{Ca} \#=100 \mathrm{Ca} /(\mathrm{Ca}+\mathrm{Mg})$ e $\mathrm{Cr} \#=100 \mathrm{Cr} /(\mathrm{Cr}+\mathrm{Al})$ by atom } \\
\hline \multicolumn{12}{|c|}{ Endmembers (mol.\%) } \\
\hline Pyrope $(\mathrm{Mg})$ & 75.43 & 76.18 & 72.63 & 77.31 & 75.23 & 69.87 & 78.19 & 76.50 & 78.65 & 74.75 & 75.16 \\
\hline Almandine $(\mathrm{Fe})$ & 14.78 & 14.79 & 15.92 & 14.61 & 15.13 & 24.76 & 14.65 & 15.13 & 14.60 & 14.36 & 14.99 \\
\hline Grossular $(\mathrm{Ca})$ & 9.79 & 9.04 & 11.45 & 8.07 & 9.65 & 5.37 & 7.16 & 8.37 & 6.75 & 10.89 & 9.85 \\
\hline
\end{tabular}




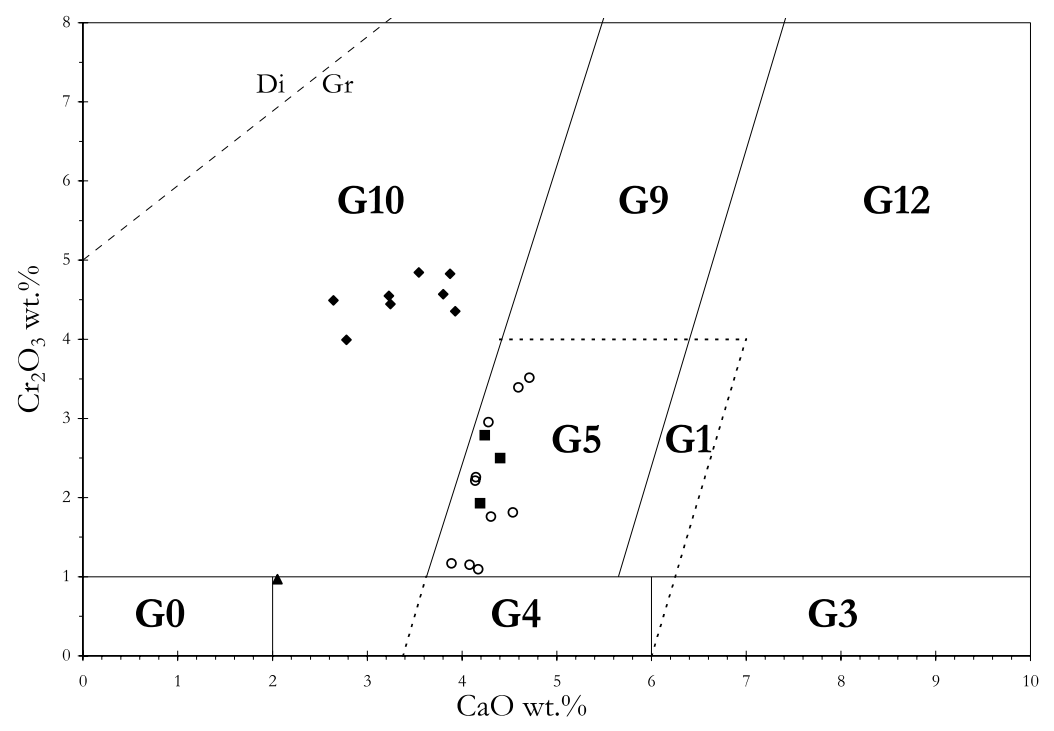

Fig. 2 - Garnets of the Camafuca-Camazambo kimberlite plotted in the genetic classification diagram of mantle-derived garnets on the basis of $\mathrm{Cr}_{2} \mathrm{O}_{3}$ and $\mathrm{CaO}$ contents, after Grütter et al. (2004). Garnets are grouped according to the G-number nomenclature: G0 (Unclassified), G1 (Low-Cr megacrysts), G3 (Eclogitic), G4 (Low-Cr Pyroxenitic/Websteritic/Eclogitic), G5 (Pyroxenitic), G9 (Lherzolitic), G10 (Harzburgitic) and G12 (Wehrlitic). G11 (High-TiO 2 peridotitic) and G1 groups were classified prior to any other (see Grütter et al. 2004) and no G11 garnets were identified. As garnets of the G2, G6, G7 and G8 groups are of crustal origin, they are not represented in this diagram. Group G1 of megacrystic garnets (stippled parallelogram) does not overlap groups G3, G4, G5, G9 or G12 since it occurs at higher $\mathrm{TiO}_{2}$ content. Garnets of group G5 are separated from G9 garnets by their Mg\# parameter. Garnets plotting above Diamond-Graphite line can be considered as being of the diamond-facies, independently of their MnO content. Garnets plotting below this line can only be considered G10D if $\mathrm{MnO}<0.36$ wt.\%. Symbols: Diamonds - G10D, Squares - G9, Circles - G1, Triangle-G4.

correct identification is very important as otherwise they may be misclassified as G9 group of garnets from lherzolites.

All G10D garnets have $\mathrm{Cr} \#(100 \mathrm{Cr} /(\mathrm{Cr}+\mathrm{Al}))$ between 12 and 14, much higher than Ca-saturated G9 garnets (between 6 and 8) and the G4 group garnet grain $(\mathrm{Cr} \#=3)$. These values are proportional to the knorringite component of garnets and are used as a useful indicator of the minimum pressure necessary for garnet crystallization. Considering a typical temperature range for diamond crystallization (900 to $1200^{\circ} \mathrm{C}$ ) on the scheme proposed by Irifune et al. (1982) for the solubility limit of knorringite molecule in pyrope as a function of pressure and temperature (Fig. 3), the analyzed G10D garnets of the Camafuca-Camazambo kimberlite require a minimum pressure of 40 to $45 \mathrm{kbar}(4-4.5 \mathrm{GPa})$ to form, inside the field of stability of diamond, which is not surprising as that this is a diamond-bearing kimberlite.

Contrasting with $\mathrm{Cr} \#, \mathrm{Mg} \#$ values $(100 \mathrm{Mg} /$ $\left.\left(\mathrm{Mg}+\mathrm{Fe}^{2+}\right)\right)$ are typically between 82 and 86 , and do not allow the distinction between garnets of the G9 and G10D groups. Again, the grain Gnt17 stands out from the set for the low value of Mg\# (74) that, in a certain way, confirms its distinct origin. The G10D garnets present Ca\# $(100 \mathrm{Ca} /(\mathrm{Ca}+\mathrm{Mg}))$ around 10 , significantly lower than the values obtained for G9 garnets (about 13).

\section{DISCUSSION}

The chemical composition of the analyzed garnets suggests that they originated in a peridotitic magma, probably of lherzolitic composition, that after a 


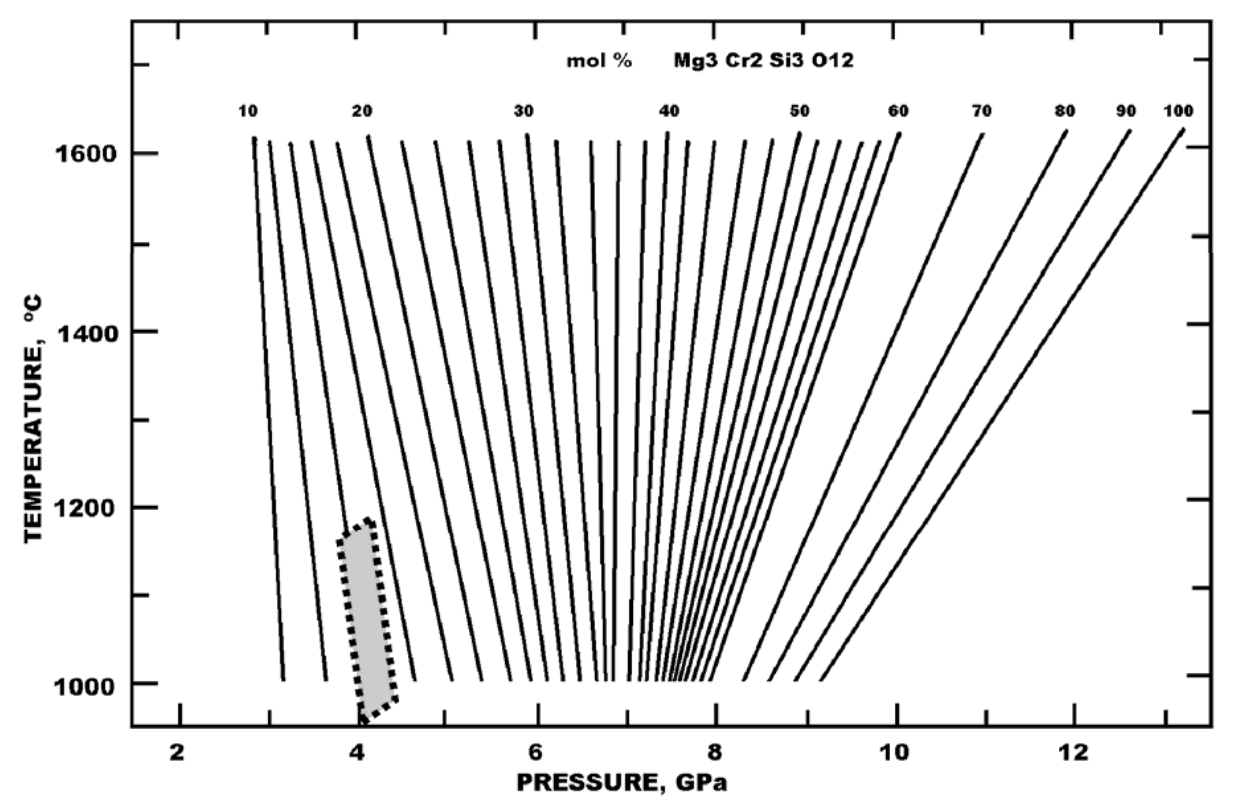

Fig. 3 - Solubility limit of knorringite molecule in pyrope as a function of pressure and temperature, after Irifune et al. (1982). Minimum pressure conditions required for the crystallization of G10D garnets of the Camafuca-Camazambo kimberlite (shaded area) were estimated by following a knorringite molecule $\left(\mathrm{Mg}_{3} \mathrm{Cr}_{2} \mathrm{Si}_{3} \mathrm{O}_{12}\right)$ composition (equivalent to the $(100 \mathrm{Cr} /(\mathrm{Cr}+\mathrm{Al}))$ index $)$ of 14 mol. $\%$ at a temperature range typical of diamond crystallization ( 900 to $1200^{\circ} \mathrm{C}$ ).

process of partial melting that produced magma of basaltic composition, left a magma of harzburgitic composition as residue. This hypothesis is corroborated by the coexistence of garnet and clinopyroxene in the same kimberlite (Laiginhas and Correia, unpublished data). Taking the molar $\mathrm{Al} / \mathrm{Cr}$ ratio in garnet as a measure for the fertility of the source (Stachel and Harris 1997), the Al/Cr ratio of G10D garnets, of about 6.5 , reflects the existence of a poorly fertile generating source of lherzolitic composition.

The chemistry of the studied garnets suggests that the Camafuca-Camazambo kimberlite sampled lherzolitic magma undergoing a depletion process at depths higher than $150 \mathrm{~km}$, which are compatible with the stability field of diamond. The occurrence of a high number of G10D garnets with compositional and pressure-temperature affinities with those generated in the field of stability of diamond is validated by the presence of diamond in the CamafucaCamazambo kimberlite.

\section{RESUMO}

Neste trabalho efetuou-se o estudo geoquímico de um conjunto de granadas, selecionadas pela cor, provenientes do kimberlito Camafuca-Camazambo, localizado no nordeste de Angola. As granadas de origem mantélica foram classificadas de acordo com o esquema proposto por Grütter et al. (2004) e pertencem aos grupos G1, G4, G9 e G10.

Foram identificadas diversas granadas sub-cálcicas (G10) e cálcicas (G9) características de harzburgitos e lherzolitos, respectivamente. O limite de solubilidade da molécula de knorringite nas granadas G10D sugere uma pressão mínima cristalização entre 40 a 45 kbar (4$4.5 \mathrm{GPa}$ ). A presença de granadas do campo de estabilidade do diamante (G10D) é indicadora do potencial diamantífero deste kimberlito. A variação química das granadas sugere uma fonte lherzolítica que após fusão parcial originou como resíduo uma rocha de composição harzburgítica.

Palavras-chave: kimberlito, diamante, granada, lherzolito, harzburgito. 


\section{REFERENCES}

GrÜtTer HS, GURney JJ, MenZies AH AND WINTER F. 2004. An updated classification scheme for mantle-derived garnet, for use by diamond explorers. Lithos 77: 841-857.

GURNEY JJ. 1984. A correlation between garnets and diamonds. In: Glover JE AND HARRIS PG (Eds), Kimberlite Occurrence and Origins: a Basis for Conceptual Models in Exploration. Geology Department and University Extension, University of Western Australia 8: 143-166.
IRIFUne T, OHTANi E AND KUMAZAWA M. 1982. Stability field of knorringite $\mathrm{Mg}_{3} \mathrm{Cr}_{2} \mathrm{Si}_{3} \mathrm{O}_{12}$ at high pressure and its implication to the occurrence of $\mathrm{Cr}$ rich pyrope in the upper mantle. Phys Earth Planet Interiors 27: 263-272.

REAL F. 1958. Sur les roches kimberlitiques de la Lunda (Angola). Bol Mus Lab Min Geo Fac Cien Univ Lisb 26: 21-33.

StAChEl T AND HARRIS JW. 1997. Syngenetic inclusions in diamond from the Birim field (Ghana) a deep peridotitic profile with a history of depletion and re-enrichment. Contrib Mineral Petrol 140: $1-15$. 